\title{
Environmental Guidance Regulatory Bulletin
}

\section{Identification and Listing of Hazardous Waste}

\section{Used Oil Final Rule and Correction Notices Issued}

Note: This Regulatory Bulletin supersedes and replaces the December 31, 1992, Used Oil Regulatory Bulletin.

\section{Introduction}

On May 20, 1992, EPA published a listing decision for used oils destined for disposal. EPA decided not to list these used oils as hazardous waste based upon the technical criteria for listing in Sections 1004 and 3001 of the Resource Conservation and Recovery Act (RCRA) and Sections 261.11(a)(1) and (3) of Chapter 40 of the Code of Federal Regulations (CFR).

A listing decision and management standards for recycled used oil were published in the Federal Register on September 10, 1992. Used oil that is recycled will not be listed as hazardous waste. The management standards that were promulgated apply to generators, transporters, processors, re-refiners, burners, and marketers of used oil and will be codified in a new 40 CFR 279. Regulations governing the burning of used oil for energy recovery
[40 CFR 266 Subpart E] have been removed from Part 266 and are now incorporated into Subparts G and $\mathrm{H}$ of the Part 279 Standards for the Management of Used Oil. Two notices correcting these used oil regulations were subsequently published on May 3, 1993, and June 17, 1993. Additional modifications of the used oil regulations may be published in response to lawsuits filed in connection with the promulgation of these regulations.

Used oil must be managed in accordance with the new 40 CFR 279 standards until it is disposed of or sent for disposal. At that point, the used oil handler must determine whether the used oil exhibits a characteristic of hazardous waste and, if it does, must dispose of the waste in accordance with the hazardous waste regulations in 40 CFR 124, 260 through 266, 268, and 270. Disposal of nonhazardous used oil must be performed in accordance with the Criteria for Classification of Solid Waste Disposal Facilities and Practices [40 CFR 257] and the Criteria for Municipal Solid Waste Landfills [40 CFR 258].

The 40 CFR 279 regulations became effective on March 8, 1993, in States that were not authorized to carry out the RCRA base program. In States authorized for the RCRA base program, but not for the former 40 CFR 266 Subpart $E$ regulations, Subparts G and H of 40 CFR 279 (formerly 40 CFR 266 Subpart E) remain federally enforceable. The other Subparts $(\mathrm{A}-\mathrm{F})$ are not enforceable until the State is granted authorization. In States authorized both for the RCRA base program and the former 40 CFR 266 Subpart E regulations, Subparts $\mathrm{G}$ and $\mathrm{H}$ of 40 CFR 279 are State enforceable; the other Subparts (A-F) are not enforceable until the State is granted authorization.

(States that have final RCRA authorization are required to modify their programs to reflect Federal program changes and to submit their 
modifications to EPA for approval. The deadline by which a State must modify its program to reflect the new rules is July 1,1994 , if a statutory change is not needed, or July 1, 1995, if a statutory change is necessary. Once EPA approves the State's submission, the State requirements become federally enforceable RCRA Subtitle C standards.)

The remainder of this regulatory bulletin describes the universe of facilities affected by the used oil regulation, the environmental contamination caused by mismanagement of used oil, the legislative and regulatory history of used oil listing decisions and management standards, the changes made by these rulemakings to the definition of hazardous waste, the applicability and contents of the new used oil management standards, State regulations applicable to used oil, other regulatory programs affecting used oil management, and remaining used oil regulatory issues.

\section{Background}

In making used oil listing determinations and developing used oil management standards, EPA had to consider:

$\square$ the large amount of used oil generated, disposed of, and recycled annually,

$\square$ the extremely large and diverse regulated community (including very small firms and some of the largest corporations in the world),

$\square$ the damages caused by mismanagement of used oil,

the variability of used oil with respect to physical and chemical characteristics and toxic constituents, and

the need to promote used oil recycling.

EPA estimated that approximately 1.35 billion gallons of used oil were generated in 1988 by households and industrial and non-industrial operations. Used oil is generated by virtually every industrial process that relies on oil for lubrication, hydraulic pressure, or insulation, and by almost every type of vehicle used for air, water, and ground transportation. EPA estimated that used oil regulations affect approximately 640,000 used oil generators and several thousand used oil transporters, processors, re-refiners, burners, and marketers. Household generators of used oil are exempt from Federal RCRA regulations but are affected by some State laws banning the disposal of used oil in municipal landfills. The majority of used oil is recycled through burning for energy recovery.

Mismanagement of used oil has caused soil, ground water, and surface water contamination. In developing used oil management standards, EPA studied used oil related damages at sites on the National Priorities List and at RCRA-permitted facilities managing used oil in solid waste management units. EPA found that, in the majority of cases, faulty used oil storage practices were the cause of these damages. Used oil stored in unlined surface impoundments, pits, ponds, and lagoons frequently leaked or overflowed to contaminate soils, surface water, ground water, sediments, and wells used as sources of drinking water. This oil often contained high levels of polychlorinated biphenyls (PCBs), lead, and halogenated solvents. EPA also found that the application of used oil contaminated with PCBs and dioxin as a dust suppressant caused environmental damage and posed a serious threat to human health. In Times Beach, Missouri, the human health threat was deemed serious enough to require the permanent relocation of homes and businesses.

As a result of these findings, EPA focused on storage practices in developing used oil management standards. To encourage recycling while protecting human health and the environment, EPA adopted measures to ensure that used oil that is disposed of (instead of recycled) would be adequately characterized before disposal. The application of used oil as a dust suppressant is now prohibited, except in States that can demonstrate that they have the resources to sufficiently control this practice. 


\section{Legislative and Regulatory History of Used oil Requirements}

Used oil regulatory requirements have been under consideration at EPA for almost 15 years. EPA first proposed regulations for the management of hazardous waste under Section 3001 of RCRA in
December 1978. A final listing decision for used oil that is disposed of was published on May 20, 1992. A final listing decision for used oil that is recycled was published on September 10, 1992, along with used oil management standards. The history of EPA decisions on used oil is summarized in the table below.

\begin{tabular}{|c|c|}
\hline \multicolumn{2}{|r|}{ Legislative and Regulatory History of Used Oil Requirements } \\
\hline Date & Legislative and Regulatory Actions \\
\hline December 18,1978 & $\begin{array}{l}\text { EPA proposes to list waste lubricating, hydraulic, and cutting oil as hazardous because of toxicity. Regulations } \\
\text { are also proposed for used oil that is recycled by being burned or incinerated and for oil that is incorporated into } \\
\text { products intended to be applied to the land. }\end{array}$ \\
\hline May 19,1980 & $\begin{array}{l}\text { EPA defers listing used oil as a hazardous waste and also defers regulating used oil recycling pending further } \\
\text { study. Used oil that exhibits any characteristic of hazardous waste is regulated when disposed of, accumulated, } \\
\text { stored, or treated. }\end{array}$ \\
\hline October 15,1980 & $\begin{array}{l}\text { Congress passes the Used Oil Recycling Act, which requires EPA to determine if used oil is hazardous, establish } \\
\text { performance standards for used oil recycling, and submit a report to Congress on the Agency's findings. }\end{array}$ \\
\hline January 1981 & $\begin{array}{l}\text { EPA submits the required report to Congress and states its intention to list both used and unused waste oil as } \\
\text { hazardous because it typically contains toxic constituents. }\end{array}$ \\
\hline November 8, 1984 & $\begin{array}{l}\text { The Hazardous and Solid Waste Amendments of } 1984 \text { are signed into law, requiring EPA to make a final } \\
\text { determination by November 8,1986, as to whether to identify any or all used oils as hazardous waste. }\end{array}$ \\
\hline November 29, 1985 & $\begin{array}{l}\text { EPA proposes to list all used oils as hazardous waste and proposes management standards for recycled used oil. } \\
\text { Final regulations are also issued prohibiting the burning of off-specification used oil fuels in non-industrial } \\
\text { boilers and furnaces. Requirements applicable to marketers and burners of used oil are promulgated. }\end{array}$ \\
\hline March 10, 1986 & EPA requests additional information on listing used oil as hazardous. \\
\hline November 19, 1986 & $\begin{array}{l}\text { EPA decides not to list as hazardous waste used oil that is recycled because the listing would "stigmatize" used } \\
\text { oil recycling and encourage improper disposal. }\end{array}$ \\
\hline October 7, 1988 & $\begin{array}{l}\text { The Court of Appeals for the District of Columbia rules that "stigmatizing" used oil recycling is not sufficient } \\
\text { grounds for EPA to decide not to list used oil as a hazardous waste. The listing decision is remanded to EPA for } \\
\text { further consideration. }\end{array}$ \\
\hline August 23, 1991 & $\begin{array}{l}\text { A consent decree lodged in the U.S. District Court for the District of Columbia requires EPA to propose } \\
\text { whether or not to list non-recycled used oil as a hazardous waste under RCRA by September 1991, } \\
\text { and to reach a final determination by May } 1992 \text {. }\end{array}$ \\
\hline September 23, 1991 & $\begin{array}{l}\text { EPA issues a supplemental notice of proposed rulemaking describing its options for regulating used oil. } \\
\text { Additional comments and data are requested from the regulated community. EPA also proposes to list as } \\
\text { hazardous four wastes from the processing and re-refining of used oil. }\end{array}$ \\
\hline May 20, 1992 & $\begin{array}{l}\text { EPA decides not to list used oils destined for disposal as hazardous waste based upon technical criteria for listing } \\
\text { in Sections } 1004 \text { and } 3001 \text { of RCRA. }\end{array}$ \\
\hline September 10, 1992 & $\begin{array}{l}\text { EPA publishes a listing decision and management standards for recycled used oil in the Federal Register. Used } \\
\text { oil that is recycled will not be listed as a hazardous waste. }\end{array}$ \\
\hline May 3, 1993 & EPA publishes technical amendments and corrections to the final rule. \\
\hline June 17,1993 & EPA publishes additional corrections to the final rule. \\
\hline
\end{tabular}




\section{Changes to the Definition of Hazardous Waste}

The used oil regulations amended the definition of hazardous waste in 40 CFR 261.3 and added exclusions to the definition in $40 \mathrm{CFR}$ 261.4. Used oils that contain more than 1,000 ppm halogens are considered to be hazardous waste because they are presumed to have been mixed with halogenated hazardous waste (listed in Subpart D of 40 CFR 261). (This presumption formerly applied only to used oil fuels.) Used oil generators may rebut this presumption by demonstrating that the used oil in question does not contain hazardous waste. This rebuttable presumption, however, does not apply to:

metalworking oils or fluids containing chlorinated paraffins, if they are processed through a tolling arrangement (as defined in 40 CFR 279.24(c)) to reclaim metalworking oils or fluids or

used oils contaminated with chlorofluorocarbons (CFCs) removed from refrigeration units where the CFCs are destined for reclamation.

Excluded from the definition of hazardous waste are:

non-terne-plated used oil filters that have been hot drained and

$\square$ used oil re-refining distillation bottoms that are used as feedstock to manufacture asphalt products.

\section{New Management Standards for Used Oil That Is Disposed of, Recycled, Re-refined, or Burned}

This section describes the applicability of the new standards for used oil management, exemptions from the standards, prohibitions of certain used oil management practices, and the management standards applicable to various segments of the used oil management system.
Applicability of the 40 CFR 279 Standards

Used oil is now regulated under 40 CFR 279 and is defined to include "any oil that has been refined from crude oil, or any synthetic oil, that has been used and as a result of such use is contaminated by physical or chemical impurities" [40 CFR 279.1].

Used oil mixed with other types of substances and regulated as used oil under 40 CFR 279 is described in the following list.

Mixtures of used oil and characteristic hazardous waste if the resultant mixture does not exhibit a characteristic of hazardous waste.

$\square$ Mixtures of used oil and conditionally exempt small-quantity generator waste.

Mixtures of used oil and other fuels or fuel products.

Used oil drained from materials containing or otherwise contaminated with used oil.

$\square$ Materials containing or otherwise contaminated with used oil that are burned for energy recovery.

Used oil that is regulated as hazardous waste under 40 CFR 124, 260 through 266, 268, and 270 is described in the following list.

Mixtures of used oil and listed hazardous wastes.

Mixtures of used oil and characteristic hazardous waste (other than hazardous waste exhibiting only the characteristic of ignitability) if the resultant mixture exhibits a characteristic of hazardous waste.

Used oil containing more than $1,000 \mathrm{ppm}$ total halogens is presumed to have been mixed with listed halogenated waste and regulated as hazardous waste unless:

- the used oil is metalworking oil or fluid containing chlorinated paraffins processed through a tolling arrangement and destined for reclamation or 
- the used oil is contaminated with CFCs from refrigeration units and the CFCs are destined for reclamation.

This presumption may be rebutted by demonstrating that the used oil does not contain listed halogenated solvents. Used oils exempted from regulation as hazardous waste may be regulated as used oil under 40 CFR 279.

Mixtures of used oil and hazardous waste exhibiting only the characteristic of ignitability (e.g., mineral spirits) are regulated as hazardous waste if they retain the ignitability characteristic and as used oil if they do not. (Such mixtures could exhibit a different characteristic (e.g., toxicity), however, and still be considered used oil.)

Materials containing or otherwise contaminated with used oil from which the used oil has been properly drained or removed (such as rags) are not regulated as used oil. Such materials have been properly drained if there are no visible signs of free-flowing oil in or on the material. (Such materials, however, may be subject to regulation as hazardous waste.)

\section{Exemptions from the 40 CFR 279 Standards}

The following are exempt from the used oil management standards:

commercial products, such as lubricants, derived from the re-refining of used oil,

mixtures of used oil and diesel fuel for use in the used oil generator's own vehicles,

re-refining distillation bottoms that are used in the manufacture of asphalt products,

wastewater discharges regulated under the Clean Water Act that are contaminated with de minimis quantities of used oil,

used oil introduced into crude or natural-gas pipelines, and

used oil on vessels.

\section{Prohibitions}

The used oil management standards contain three types of prohibitions: (1) the management of used oil in surface impoundments and waste piles is prohibited unless these units are subject to regulation under 40 CFR 264 or 265 ; (2) the use of used oil as a dust suppressant is prohibited unless it takes place in a State authorized by EPA to allow this practice; and (3) the burning of off-specification used oil fuel is prohibited unless it is burned in one of the following:

$\square$ an industrial furnace meeting the definition in 40 CFR 260.10,

$\square$ an industrial boiler meeting the definition in 40 CFR 260.10,

a used oil-fired space heater burning used oil generated on site, with a maximum capacity of not more than 0.5 Btu per hour and with combustion gases from the heater vented to the outside air, or

$\square$ a hazardous waste incinerator subject to regulation under 40 CFR 264 or 265.

Off-specification used oil fuels are those that contain more than $5 \mathrm{ppm}$ arsenic, $2 \mathrm{ppm}$ cadmium, $10 \mathrm{ppm}$ chromium, $100 \mathrm{ppm}$ lead, or 4,000 ppm total halogens, or those not having a flash point of at least $100^{\circ} \mathrm{F}$. (Additional specifications for used oil fuels containing PCBs are contained in 40 CFR 761.20(e).)

\section{Management Standards}

The 40 CFR 279 management standards contain subparts applicable to:

used oil generators (Subpart C),

used oil collection centers and aggregation points (Subpart D),

used oil transporters and transfer facilities (Subpart E),

used oil processors and re-refiners (Subpart F), 
used oil burners who burn off-specification used oil for energy recovery (Subpart G),

used oil fuel marketers (Subpart $\mathrm{H}$ ), and

use of used oil as a dust suppressant and disposal of used oil (Subpart I).

Facility owners and operators regulated under 40 CFR 279 must comply with all subparts applicable to the activities they perform.

\section{Generators}

A used oil generator is defined in $40 \mathrm{CFR}$ 279.1(a) as "any person, by site, whose act or process produces used oil or whose act first causes used oil to become subject to regulation." The major requirements applicable to used oil generators are summarized below.

Used oil generators are required to store used oil in tanks, containers, or units subject to regulation under 40 CFR 264 or 265 [\$279.22].

( Above-ground tanks or containers storing used oil are required to be "in good condition" and "not leaking" [\$279.22(b)]. (Regulations promulgated under 40 CFR 280 are applicable to underground storage tanks containing used oil.)

Containers, above-ground tanks, and fill pipes used to transfer used oil into underground storage tanks at generator facilities must be clearly marked with the words "Used Oil" [\$279.22(c)].

Upon detection of a release of used oil to the environment, a generator must stop, contain, and clean up the release, and make any repairs necessary to used oil tanks and containers to prevent future used oil releases.

Used oil generators are responsible for ensuring that their used oil is moved only by transporters who have obtained an EPA identification number. However, a used oil generator may transport up to 55 gallons of used oil to a used oil collection center or on-site aggregation point without obtaining an EPA.identification number (and being considered a used oil transporter). A generator may also arrange for the used oil to be moved by a transporter without an EPA identification number provided that the used oil is destined for reclamation under a tolling arrangement.

\section{Transporters}

Used oil transporters must obtain EPA identification numbers and are responsible for determining that the used oil they are transporting or storing is not hazardous under the $1,000 \mathrm{ppm}$ halogens rebuttable presumption. Used oil transporters are also responsible for tracking used oil shipments. The requirements applicable to the storage of used oil and response to releases at transporters' transfer facilities are identical to those applicable to generators except that the used oil storage tanks and containers at transporters' transfer facilities must be equipped with secondary containment systems.

\section{Processors and Re-refiners}

Used oil processors and re-refiners are subject to the most extensive set of used oil management requirements. These standards are applicable to owners and operators of facilities that process used oil. Processing means "chemical or physical operations designed to produce from used oil, or to make used oil more amenable for production of fuel oils, lubricants, or other used oil-derived products. Processing includes, but is not limited to, blending used oil with virgin petroleum products, blending used oils to meet the used oil fuel specifications, filtration, simple distillation, chemical or physical separation, and re-refining" [40 CFR 279.50(a)].

Used oil processors and re-refiners are responsible for obtaining an EPA identification number, tracking shipments of used oil that are accepted and delivered, keeping an operating record, reporting biennially on the amount of used oil processed or re-refined and the processes used, and developing a written plan describing the procedures for sampling used oil. Processors and re-refiners may have to sample the used oil to determine whether or not it is hazardous under the rebuttable presumption or whether it is an off-specification or on-specification used oil fuel.

The requirements applicable to the storage of 
used oil and response to releases at processor and re-refiner facilities are identical to those applicable to generators except that the tanks and containers storing used oil at processor and re-refiner facilities must be equipped with secondary containment systems. In addition, processors and re-refiners must decontaminate above-ground tanks and containers at closure and perform closure and post-closure care [40 CFR 279.54(h)] in areas where soils contaminated by aboveground tanks cannot be decontaminated or removed.

Processors and re-refiners are also subject to an extensive set of general facility standards involving preparedness and prevention and contingency plan and emergency procedures. The preparedness and prevention provisions are identical to those established for hazardous waste management facilities in 40 CFR 265 Subpart C. These requirements pertain to maintenance and operation of the facility, required equipment, testing and maintenance of the equipment, access to a communication or alarm system, required aisle space, and arrangements with local authorities. The contingency plan and emergency procedures are identical to those established for hazardous waste management facilities in 40 CFR 265 Subpart D. These requirements pertain to the purpose and implementation of contingency plans, the content of contingency plans, copies of contingency plans, amending contingency plans, the emergency coordinator, and emergency procedures.

\section{Burners}

The used oil management standards applicable to burners of off-specification used oil fuels in the former 40 CFR 266 Subpart E regulations are now located in 40 CFR 279 Subpart G. Burners of offspecification used oil fuels must (1) comply with the notification requirements of RCRA Section 3010 and obtain an EPA identification number, (2) ensure that the used oil is not hazardous waste by determining whether the total halogen content of used oil managed at the facility is above or below $1,000 \mathrm{ppm}$, and (3) keep a record of each used oil shipment accepted for burning. (Off-specification used oil fuels were defined previously in the section on Prohibitions.) New requirements applicable to the storage of used oil and response to releases at facilities that burn off-specification used oil fuel are identical to those applicable to generators except that the tanks and containers storing used oil at facilities burning off-specification used oil fuel must be equipped with secondary containment systems.

\section{Marketers}

The used oil management standards applicable to used oil fuel marketers are basically the same as they were in the former 40 CFR 266 Subpart E regulations. Used oil fuel marketers must comply with the notification requirements of RCRA Section 3010 and obtain an EPA identification number. A used oil fuel marketer must determine whether used oil fuel being offered for sale meets the used oil fuel specifications. On-specification used oil fuel is not subject to further regulation. Marketers may only send off-specification used oil fuel to industrial furnaces or industrial boilers with EPA identification numbers. Used oil fuel marketers must keep records of all shipments of on-specification and off-specification used oil fuels.

\section{State Regulation of Used OiI}

Between 1980 and 1992, many States adopted their own regulations governing the management of used oil. To the extent that these regulations are more strict or broad than the Federal requirements, they will continue to apply to used oil management. Examples of State regulations that are more strict are:

regulation of used oil as a hazardous waste in California, Massachusetts, Missouri, New Jersey, Rhode Island, and Vermont and

bans on the disposal of used oil in municipal landfills in Connecticut, Florida, Iowa, Louisiana, Maryland, Massachusetts, Michigan, Minnesota, Missouri, New Jersey, New York, North Carolina, Rhode Island, South Carolina, Vermont, Wisconsin, and the District of Columbia. 


\section{Applicability of Other Environmental Regulations to Used OiI}

In addition to the new 40 CFR 279 standards and State regulations, regulations promulgated under other environmental laws affect the management, recycling, transportation, and disposal of used oil. Some of these regulations are listed below.

According to regulations promulgated under the Toxic Substances Control Act, the burning of used oil containing detectable levels ( $2 \mathrm{ppm}$ ) of PCBs in non-industrial boilers or furnaces is prohibited. The PCB limit for off-specification used oil fuels is $50 \mathrm{ppm}$.

Used oil handlers must comply with all applicable requirements of the Spill Prevention Control and Countermeasures Program established under the Clean Water Act. These requirements are contained in 40 CFR 112.

Used oil stored in underground storage tanks (USTs) is regulated under Subtitle I of RCRA. The UST regulations are found in 40 CFR 280.

\section{Remaining Used Oil Regulatory Issues}

\section{Residuals from Used Oil Re-Refining and Processing}

Pending further study, EPA has not yet decided whether residuals and sludges from used oil. re-refining and processing should be listed as hazardous waste. However, distillation bottoms from the re-refining of used oil are conditionally exempt from 40 CFR 279 (and the hazardous waste regulations in 40 CFR 124, 260 through 266, 268, and 270) if they are used as ingredients in asphalt paving and roofing materials. Data submitted to EPA showed that distillation bottoms from rerefining processes do not exhibit the toxicity characteristic for hazardous waste.

\section{Burning of Used Oil}

EPA intends to study issues associated with the burning of on-specification and off-specification used oil fuel. Environmental groups and several States have suggested that the $100 \mathrm{ppm}$ specification level for lead is too high given the large amounts of used oil that are burned for energy recovery.

Methods to Encourage Used Oil Recycling by Do-it-Yourselfers (DIY-ers)

Much of the used oil that is not recycled is generated by DIY-ers (i.e., persons who change their own automotive crankcase oil). EPA is studying public and private programs to encourage used oil recycling by DIY-ers and may develop incentive programs to encourage used oil recycling by this segment of used oil generators.

Please direct questions about the

$R C R A$ final rule on used oil to:

Mark Petts

DOE Office of Environmental Guidance

RCRA/CERCLA Division, EH-231

1000 Independence Ave., S.W.

Washington, D.C. 20585

FTS 896-2609

(202) 586-2609. 